\title{
Water Distribution in a Fire Protection System (Case Study Of DKK Semarang Building Simulation by Epanet 2.0)
}

\author{
Yanuar Ali Nurhakim ${ }^{1, \text { a) }}$ and Karuniadi Satrijo Utomo ${ }^{1, \text { b) }}$

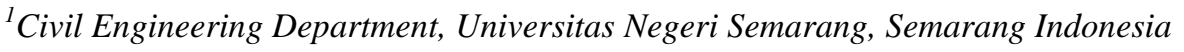

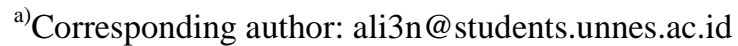 \\ b)utomo@mail.unnes.ac.id
}

\begin{abstract}
Fire is a disaster that must be avoided in various ways, one of them is by using a fire extinguishing system to prevent fire disaster. This study used the Semarang City Health Office (DKK) Building as a sample. The purposes of this research were; (1) to find out whether the application of the fire protection system at DKK Building has met the regulations and (2) to determine whether the water distribution in the fire protection system in the Semarang DKK Building is functioning properly as needed. Data collection methods in this study consisted of observation and literature study. The observation was used to find research data in the form of planning drawings on the building protection system and the literature study was carried out to obtain data in the form of standard tool specifications and rules for using tools in the protection system. This study also used an analysis method based on an application program called Epanet 2.0. The Epanet program was used to simulate a hydraulic model according to the fire protection system at DKK Building. The results of the analysis using the Epanet 2.0 show that the sprinkler system has met the needs based on the amount of water supply discharge and based on the required pressure. The underground tank volume of $150 \mathrm{~m} 3$ has met the requirements based on SNI 03-39892000. The pressure value for all sprinklers has met the requirements of SNI 03-3989-2000 with the smallest pressure value is $2.5 \mathrm{kgf} / \mathrm{cm}^{2}$. The sprinkler system does not meet the water distribution value set in NFPA 13 with a maximum distribution time of 50 seconds while the analysis results show that the distribution time is 205 seconds. The pressure value at all points of the fire hydrant system meets the SNI 03-1745-2000 rules with a maximum value not exceeding 24.1 bars. The pressure value at the farthest hydrant box hose connection does not meet the SNI 03-1745-2000 rules with the pressure value at the farthest hydrant box is 4.6 bars, where is the minimum pressure is 6.9 bars.
\end{abstract}

Keywords: fire, protection, epanet 2.0 simulation. 


\section{INTRODUCTION}

Semarang City Health Office (DKK) building was built in the early of 2019, which has 3 main functions, as well as office, health center and a parking building. The building has 10 floors and 1 basement. The $1^{\text {st }}$ and $2^{\text {nd }}$ floors are used for Puskesmas/ health center, $9^{\text {th }}, 10^{\text {th }}$ floor and basement are for the Health Office and $3^{\text {rd }}-8^{\text {th }}$ floors are as parking area. Because of the imperative of the building, the building safety system such as fire need to be considered.

Fire is a thermo chemical reaction caused by oxygen, fuel, and heat. The combination of these factors causes a fire event that generates heat, flames, smoke, and gas. The products of fire cause disaster in the building area. Material losses, stagnation of business activities, environmental damage and losses of human life are the consequences of the fire disaster [5]. The occurrence of building fires is unpredictable. Therefore, fire prevention activities must recognize and eliminate the potential activities that cause a fire [1].

Fire prevention activity in DKK Building uses automatic sprinklers system and hydrants. The systems follow the regulation in the National Standardization Agency of Indonesia (SNI No. 03-3989-2000) with reference to Technical Requirements of Fire Protection Systems in Buildings and the Environment [2] and SNI 03-1745-2000 pertaining to procedures for installing vertical pipes and hoses [3].

Based on the code, water availability, pressure and velocity in the fire protection systems must be able to extinguish each spot of fire in building area by manual or automatic systems [2]. Haramain et al [6] has examined the design of fire extinguishing systems in offices and factories. Putri [7] has also examined the design and analysis of automatic sprinkler systems and firefighting hotels using manual calculations. Both studies only calculated the farthest point. However, there is a pressure rule at every point in the sprinkler and hydrant systems. weakness in manual calculation is that we have to calculate the point-by-point system pressure of the pipeline. We need the entire system pressure result to determine whether the pipe system meets SNI standards.

This study used the Epanet 2.0 application program to simulate the system. We can find all the result by Epanet 2.0 to define is the building has fulfilled the standard. With this research, it is expected to be able to encourage other facilities to improve the security in the form of a fire extinguisher system to functions precisely and efficiently. 


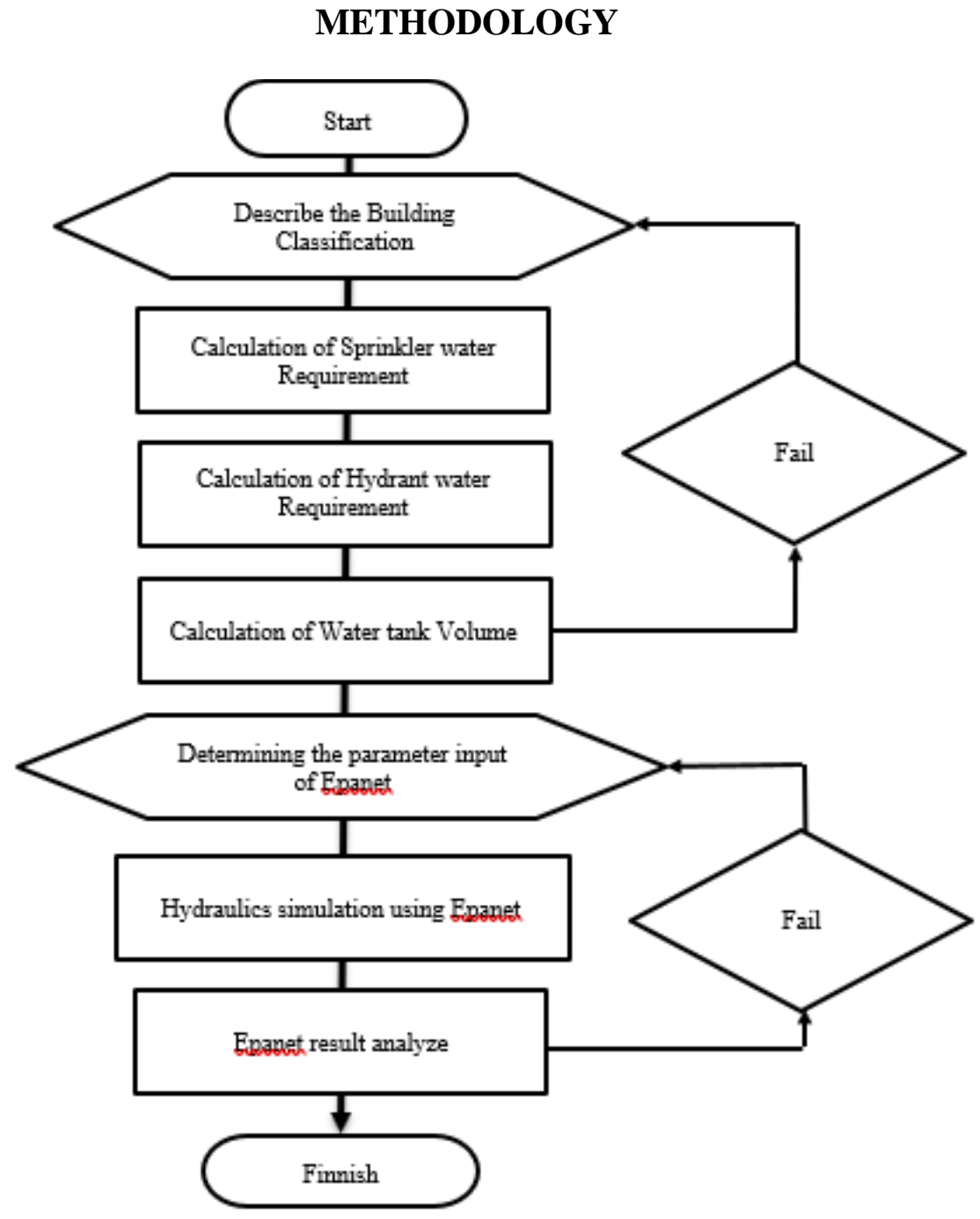

FIGURE 1. Calculations Methods

- Calculation of the number of hydrant and sprinklers.

We need to calculate all the sum of hydrant and sprinkler to calculate the fire system water requirement.

- Calculation of building water requirements.

This method was used to determine the building water demand based on the building usage, plumbing tools and fire installation.

- Calculation of the dimensions of the underground tank.

To determine the volume of underground water tank.

- Calculation of fire protection system pump capacity.

To calculate the pump capacity to fulfill the requirement head based on the pipe installation.

- Hydraulic simulation using Epanet 2.0.

To simulate the building water system and find the result to determine whether the system has met the requirements based on the existing standard. 


\section{RESULT AND DISCUSSION}

a. Building clasifications

DKK Semarang building has 3 main functions, such as an office building, a service health care (puskesmas) and parking spaces. According to SNI 03-3989-2000, offices and puskesmas are light fire dwellings, while the parking building is a medium class fire dwellings [2].

b. Type of sprinkler and hydrant

Based on the results of observations in Semarang City Health Office building, data in the form of sprinkler specifications are as follows:

- Upward sprinkler being installed for parking spaces.

- Down sprinkler being installed for offices and health centers.

- Sensitivity to temperature, the color of the liquid in a glass tube is red at $60^{\circ} \mathrm{C}$.

- Sprinklers used is 0.5-inch size with a capacity (Q) of 25 GPM or 93.33 liters / minute, the radiation density is $15 \mathrm{~mm} /$ minute [2].

- $\quad$ Sprinkler pipe capacity $=946$ liters/minute [3].

- Protected areas are all rooms except the toilet / bathroom and stairs. While the data for hydrant installed at the building are as follows:

- Indoor hydrant box is installed using a 2,5-inch hose connection with a residual pressure is 6,9 bars;

- Hydrant pipe flow capacity is 2081,75 liters/minute;

- Hydrant pillar uses a 2,5-inch output size;

- The discharge on the pillar hydrant 1 is 38 liters/second and dthe discharge for the pillar hydrant 2 is 19 liters/second [3].

\section{Fire Equipment Data}

TABLE 1. Data for sanitary equipment.

\begin{tabular}{cccc}
\hline Floor & Sprinkler & Hydrant box & $\begin{array}{c}\text { Pillar } \\
\text { Hydrant }\end{array}$ \\
\hline 0 & 40 & 3 & 0 \\
1 & 28 & 3 & 2 \\
2 & 23 & 3 & 0 \\
3 & 22 & 3 & 0 \\
4 & 51 & 3 & 0 \\
5 & 51 & 3 & 0 \\
6 & 51 & 3 & 0 \\
7 & 51 & 3 & 0 \\
8 & 51 & 3 & 0 \\
9 & 54 & 3 & 0 \\
10 & 54 & 3 & 0 \\
\hline Total & $\mathbf{4 7 6}$ & $\mathbf{3 3}$ & $\mathbf{2}$ \\
\hline
\end{tabular}



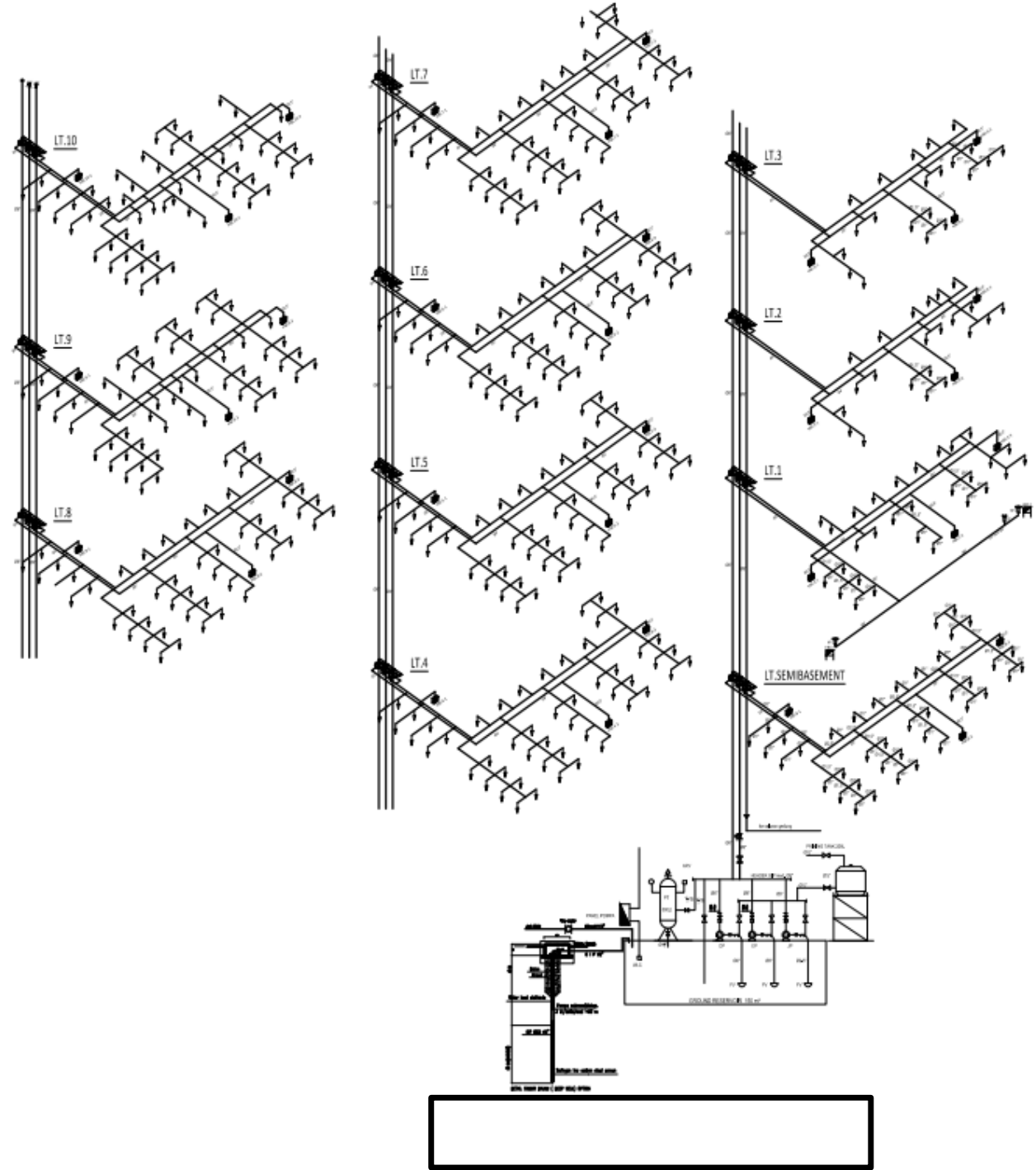

FIGURE 2. Fire protection system diagram

Fire protection system planning

- Water requirement for the sprinkler system was calculated using this following formula:

Where

$$
Q s=Q / \text { ssprinkler }
$$

$$
\begin{array}{ll}
\mathrm{Qs} & =\text { Sprinkler demand }(1 / \text { minute }) \\
\begin{array}{l}
\text { sprinkler } \\
\mathrm{Q}
\end{array} & \text { Total sprinkler used } \\
& =\text { Sprinkler capacity }(9461 / \text { minute }) \\
Q s=946 / 476 \\
\text { Qs }=1,9874 \frac{\text { liter }}{\text { minute }}
\end{array}
$$

- Water requirement for the hydrant system was calculated using this following formula:

Where

$$
Q h b=Q / \text { Shydrant }
$$

Qhb $\quad=$ Hydrant box demand (liter/minute)

Q $\quad=$ Hydrant pipe capacity (2081,75 liter/minute)

$\Sigma_{\text {hydrant }}=$ Hydrant used

$$
Q h b=2081,75 / 33
$$




$$
Q h b=63,083 \frac{\text { liter }}{\text { menit }}
$$

Demand on pillar hydrant is in accordance with SNI 03-1745-2000, which is not less than 38 liters/second at 3,5 bars for the first hydrant and 19 liter/seconds at 3,5 bars for the second and another hydrant.

- Ground Water Tank (GWT) Capacity

To calculate the underground water tank capacity (GWT), it used the following formula:

$$
V r=Q h-Q s
$$

where:

$\mathrm{Vr} \quad$ : bottom water tank volume (liters)

Qh : Amount of water requirement per hour (181680 liters/use)

Qs : Source Pipe (2/3 x Qh)

Therefore :

$$
\begin{gathered}
V r=181680-\left(\frac{2}{3} \times 181680\right) \\
V r=60,56 \mathrm{~m}^{3}
\end{gathered}
$$

Beside on SNI 03-0989-2000 about water sprinkler system for building fire extinguisher, ground water tank minimum capacity for building with medium class 1 [6] with the table below.

TABLE 2. Minimum water tank capacity

\begin{tabular}{cccc}
\hline Class & $\begin{array}{c}\text { Maximum height } \\
\text { between the lower and } \\
\text { higher sprinkler }(\mathbf{m})\end{array}$ & $\begin{array}{c}\text { Minimum } \\
\text { Capacity } \\
\left(\mathbf{m}^{\mathbf{3}}\right)\end{array}$ & $\begin{array}{c}\text { Maximum filling time } \\
\text { for suction tank } \\
\text { (minute) }\end{array}$ \\
\hline I & 15 & 55 & 60 \\
& 30 & 70 & 60 \\
45 & 80 & 60 \\
II & 15 & 105 & 60 \\
& 30 & 125 & 60 \\
& 45 & 140 & 60 \\
III & 15 & 135 & 60 \\
& 30 & 160 & 60 \\
& 45 & 185 & 60 \\
\hline
\end{tabular}

- Pump capacity

In this case, DKK building using 3 types of pumps, which is electric pump and diesel pump as

\begin{tabular}{|c|c|c|c|}
\hline Pump specification & $\mathbf{J P}$ & EP & DP \\
\hline Capacity, GPM & 50 & 750 & 750 \\
\hline Head, M & 95 & 90 & 90 \\
\hline Power, kW & 5,5 & 65 & 65 \\
\hline RPM & 2900 & 2900 & 2900 \\
\hline Type & \multicolumn{3}{|c|}{ Self Priming Sentrifugal } \\
\hline Total & 1 & 1 & 1 \\
\hline Location & \multicolumn{3}{|c|}{ Ruang Pompa } \\
\hline
\end{tabular}
the main pump and a jokey pump as a pressure booster. The diesel pump as a backup from the electric pump.

TABLE 3. Pump specification.

- Hydraulics simulation using Epanet 2.0 


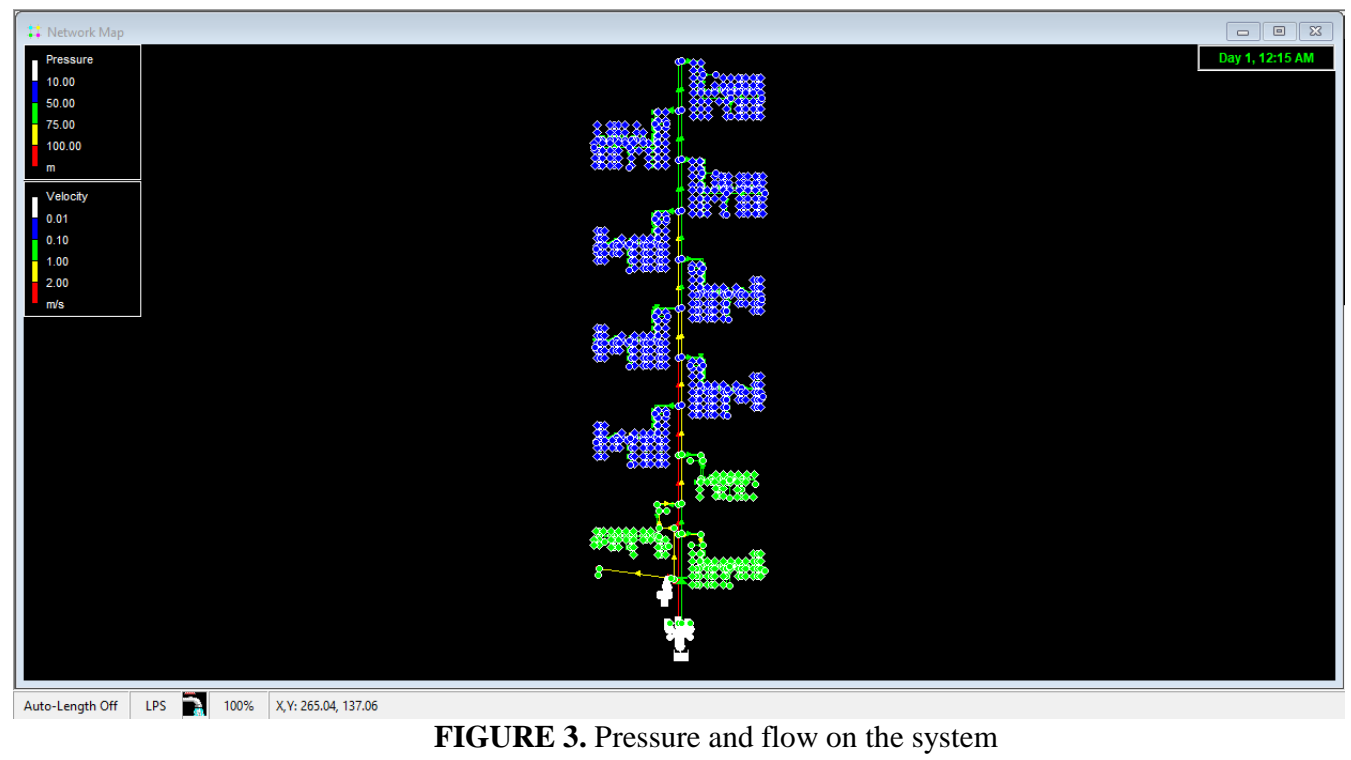

Based on SNI 03-3989-2000, the minimum pressure on each sprinkler for class I medium fire hazard is 0,7 bars. From Figure 2, we know that the nodes in blue represent the pressure values between 1- 5 bars, while the nodes in green represent the pressure values of 5 -7,5 bars. and yellow color at 7,5-10 bars. Based on the description, the results of the pressure at each sprinkler point meet the requirements with the lowest point in the range of 1-5 bar.

In addition, SNI 03-1745-2000 also limits the pressure at any point anywhere in the pipe system not to exceed 24.1 bars. In the analysis, it is known that the point with the highest pressure is the point with green color ranging from 5-7.5 bar, the system has met the pressure requirements. In addition to the SNI 03-1745-2000 system, it is explained that the farthest hydrant box is hydraulically designed to obtain the water flow rate at a residual pressure of 6.9 bar (100 psi) at the farthest $65 \mathrm{~mm}\left(2 \frac{1}{2} \mathrm{inch}\right)$ hose connection output calculated hydraulically. The results of the epanet output on the farthest hydrant box, namely node J552, get a pressure value of 4.6 bar, so it does not meet the requirements.

\begin{tabular}{|l|l|}
\hline \multicolumn{2}{|l}{ Junction J646 } \\
\hline Property & Value \\
\hline *Junction ID & $J 646$ \\
\hline X-Coordinate & 89.00 \\
\hline Y-Coordinate & 84.00 \\
\hline Description & \\
\hline Tag & \\
\hline *Elevation & 12.5 \\
\hline Base Demand & 0.99 \\
\hline Demand Pattern & H \\
\hline Demand Categories & 1 \\
\hline Emitter Coeff. & \\
\hline Initial Quality & \\
\hline Source Quality & \\
\hline Actual Demand & 0.99 \\
\hline Total Head & 57.15 \\
\hline Pressure & 44.65 \\
\hline Quality & 0.00 \\
\hline & \\
\hline
\end{tabular}

FIGURE 4. Pressure on the farthest hydrant box 


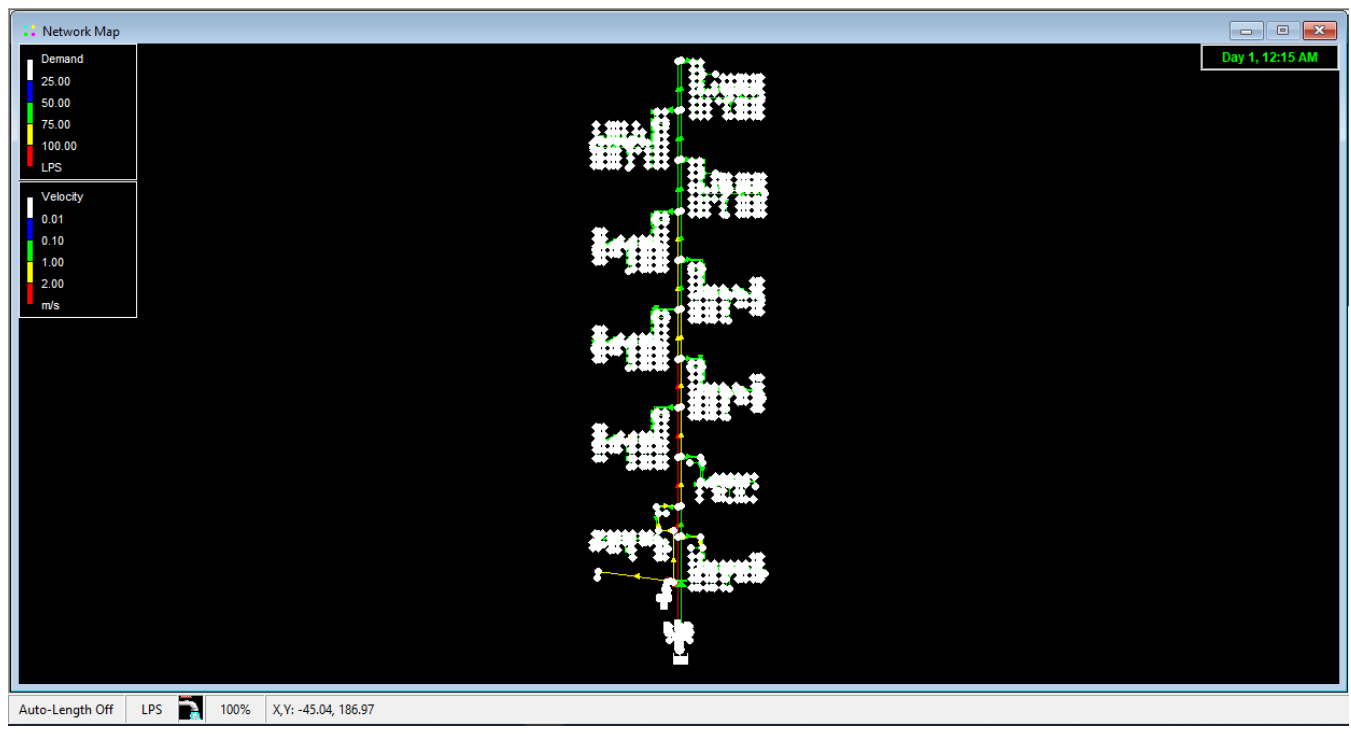

FIGURE 5. Demand and velocity

Figure 4 explains the demand for water at the node and velocity of the pipe. The color of the node with different needs is explained. Nodes in white are nodes with water requirements of 0 0.05 , nodes in blue are nodes with water requirements of 0.05-1 liter / second. Then the green node is the node with a water requirement of 1-10 liters / second. And the last node in yellow is a node with a water requirement of 10-100 liters / second. Flow velocity in Figure 4 is depicted with pipes that have a different color. The figure explains the color difference parameters of the pipe. The blue color on the pipe indicates the flow velocity ranging from $0.01-0.1 \mathrm{~m} / \mathrm{sec}$, the green pipe shows the flow velocity ranging from $0.1-1 \mathrm{~m} / \mathrm{sec}$, then the yellow pipe shows the flow velocity ranging from $1-2 \mathrm{~m} / \mathrm{sec}$ and the pipe in red indicates a flow rate of $>2 \mathrm{~m} / \mathrm{sec}$.

The table below shows the length of time for water distribution in a dry pipe system as stipulated in the NFPA 13 2007[4] edition on the Standard of the Installation Sprinkler System.

TABLE 4. Water distribution time

\begin{tabular}{lccl} 
& \multicolumn{2}{c}{ TABLE 4. Water distribution time } \\
\hline Hazard & $\begin{array}{c}\text { Number of Most } \\
\text { Remote Sprinklers } \\
\text { Initially Open }\end{array}$ & $\begin{array}{c}\text { Maximum Time of } \\
\text { Delivery }\end{array}$ \\
\hline Residential & 1 & 15 & seconds \\
Light & 1 & 60 & seconds \\
Ordinary I & 2 & 50 & seconds \\
Ordinary II & 2 & 50 & seconds \\
Extra I & 4 & 45 & seconds \\
Extra II & 4 & 45 & seconds \\
High piled & 4 & 40 & seconds \\
\hline
\end{tabular}

Based on the table above, we need to analyze the flow velocity against the distribution time by simulating 2 open sprinklers at the farthest distance. The following table is the result of calculated pipe velocity from the pump to the farthest sprinkler point.

TABLE 5. Distribution time

\begin{tabular}{ccccccccc}
\hline \multirow{2}{*}{ Pipe } & velocity & length & time & & & velocity & length & Time \\
\cline { 2 - 3 } & $\mathrm{m} / \mathrm{s}$ & $\mathrm{mm}$ & $\mathrm{sec}$ & pipe & & $\mathrm{m} / \mathrm{s}$ & $\mathrm{mm}$ & $\mathrm{sec}$ \\
\hline P548 & 0.44 & 1800 & 4.09 & $\mathrm{P} 478$ & & 0.87 & 3600 & 4.14 \\
P547 & 0.57 & 3600 & 6.32 & $\mathrm{P} 477$ & 0.91 & 3600 & 3.96 \\
P546 & 0.49 & 3600 & 7.35 & $\mathrm{P} 476$ & 0.95 & 3600 & 3.79 \\
P545 & 0.74 & 5200 & 7.03 & & P475 & 0.98 & 1000 & 1.02 \\
\hline
\end{tabular}




\begin{tabular}{lccccccc}
\hline P489 & 0.78 & 1800 & 2.31 & P18 & 0.44 & 3500 & 7.95 \\
P488 & 0.54 & 3600 & 6.67 & P17 & 0.88 & 3500 & 3.98 \\
P487 & 0.58 & 1800 & 3.10 & P16 & 1.37 & 3500 & 2.55 \\
P486 & 0.73 & 1800 & 2.47 & P15 & 1.78 & 3000 & 1.69 \\
P485 & 0.76 & 3600 & 4.74 & P14 & 2.21 & 3000 & 1.36 \\
P484 & 0.86 & 1600 & 1.86 & P13 & 2.65 & 3000 & 1.13 \\
P483 & 0.95 & 1000 & 1.05 & P12 & 3.1 & 3000 & 0.97 \\
P482 & 0.98 & 1000 & 1.02 & P11 & 3.56 & 3000 & 0.84 \\
P481 & 1.08 & 3600 & 3.33 & P10 & 3.78 & 3500 & 0.93 \\
P480 & 1.11 & 6600 & 5.95 & P9 & 4.06 & 4000 & 0.99 \\
P479 & 0.84 & 2000 & 2.38 & P8 & 4.45 & 2800 & 0.63 \\
& total & & 59.65 & & total & & 35.92 \\
\hline
\end{tabular}

Table 5 shows the maximum value of the water distribution time to the sprinkler point, which is 50 seconds, while the manual calculation results in table 4.6 based on the epanet program output are 95.57 seconds. These results indicate that the average water velocity in the distribution pipe is too small and the distribution time of water does not meet the standard of NFPA 13 2007[4].

c. Discussion

Based on the results of the analysis above, the comparison results from field data and calculation data are against rules and standards including the following.

TABLE 7. Comparison of anaysis results with standards and field data.

\begin{tabular}{lcccc}
\hline \multicolumn{1}{c}{ Parameter } & Standard & $\begin{array}{c}\text { Analysis } \\
\text { result }\end{array}$ & Field data & Information \\
\hline Maximum sprinkler uses & 1000 & - & 476 & Qualify \\
Sprinkler minimum pressure & $0,7 \mathrm{bar}$ & $1 \mathrm{bar}$ & - & Qualify \\
Hydrant box farthest pressure & $6,9 \mathrm{bar}$ & $4,6 \mathrm{bar}$ & - & Not eligible \\
Maximum pressure on the system & $24,1 \mathrm{bar}$ & $7,5 \mathrm{bar}$ & - & Qualify \\
GWT capacity & $70 \mathrm{~m} 3$ & $60,56 \mathrm{~m} 3$ & $150 \mathrm{~m} 3$ & Qualify \\
Minimum pump capacity & 3100 & - & 3100 & Qualify \\
Suction pipe minimum diameter & $150 \mathrm{~mm}$ & - & $150 \mathrm{~mm}$ & Qualify \\
Discharge pipe minimum diameter & $150 \mathrm{~mm}$ & - & $150 \mathrm{~mm}$ & Qualify \\
Maximum distribution time & $50 \mathrm{~seconds}$ & 95,57 & - & Not eligible \\
\hline
\end{tabular}

\section{CONCLUSION}

Based on the results of data analysis explained above, it can be concluded as follows:

a. The use of tools in the Semarang DKK building protection system has met the applicable provisions based on SNI regulation;

b. The distribution system on the sprinkler and hydrant pipes can distribute water throughout the sprinkler and hydrant units. However, there are shortcomings in the form of distribution time that exceeds the maximum requirement and there are several hydrants that do not meet the minimum pressure so that the distribution system on the sprinkler and hydrant pipes is still not sufficient. 


\section{REFERENCES}

[1] Menteri Pekerjaan Umum, Permenpu No. 26/PRT/M/2008 Persyaratan Teknis Sistem Proteksi Kebakaran pada Bangunan Gedung dan Lingkungan, Jakarta: Kementrian Pekerjaan Umum. 2008.

[2] Badan Standarisasi Nasional. SNI 03-3989-2000. Tata Cara Perencanaan dan Pemasangan Sistem Sprinkler Otomatik UntukPencegahan Bahaya kebakaran pada Bangunan gedung. Jakarta: Dewan Standarisasi Indonesia. 2000.

[3] Badan Standarisasi Nasional. SNI 03-1745-2000. Tentang Tata Cara Pemasangan pipa tegak dan slang. Jakarta: Dewan Standarisasi Indonesia. 2000.

[4] National Fire Protection Association (NFPA) 13 tahun 2007. Tentang Standart for the Installation of Sprinkler Systems.

[5] Suprapto. 1998. Fire Safety in Building and Housing. Masalah Bangunan. Vol. 38 No.1-4. Jakarta.

[6] Haramain, Muhammad Al et al. 2017. Perancangan Sistem Pemadam Kebakaran pada Perkantoran dan Pabrik Label Makanan PT XYZ dengan Luas Bangunan 1125 M2. Jurnal Mesin Teknologi (SINTEK Jurnal) Vol. 11 No. 2 Desember 2017, pp. 129-150.

[7] Putri, Rahesa Dwi. 2017. Perencanaan dan Analisa Sistem Sprinkler Otomatis dan Kebutuhan Air Pemadaman Fire Fighting Hotel XX. Jurnal Teknik Mesin (JTM) Vol. 06 No. 1 Februari 2017, pp. 6-12. 